\title{
A (too) bright future? Arctic diatoms under radiation stress
}

\author{
Eva Leu $^{1,2}$ (1) $\cdot$ Martin Graeve $^{3} \cdot$ Angela Wulff $^{4}$
}

Received: 17 September 2014/Revised: 1 July 2016/Accepted: 1 July 2016/Published online: 9 August 2016

(C) Springer-Verlag Berlin Heidelberg 2016

\begin{abstract}
Decreasing Arctic sea ice cover and increasing stratification of ocean surface waters make the exposure of pelagic microalgae to high irradiances more likely. Apart from light being a necessary prerequisite for photosynthesis, rapidly changing and/or high irradiances are potentially detrimental. An in situ study was performed in the high Arctic $\left(79^{\circ} \mathrm{N}\right)$ to determine the effect of high irradiances in general, and ultraviolet radiation (UVR, 280-400 nm) in particular, on cell concentrations, fatty acid composition, and photoprotective pigments of three diatom species isolated from seawater around Svalbard. Unialgal cultures were exposed in situ at 0.5 - and $8 \mathrm{~m}$-depth. After $40 \mathrm{~h}$, cell concentrations of Synedropsis hyperborea and Thalassiosira sp., were lower at 0.5 than at $8 \mathrm{~m}$, and the content of the photoprotective xanthophyll-cycle pigment
\end{abstract}

This article belongs to the special issue on the "Kongsfjorden ecosystem-new views after more than a decade of research", coordinated by Christian Wiencke and Haakon Hop.

Electronic supplementary material The online version of this article (doi:10.1007/s00300-016-2003-1) contains supplementary material, which is available to authorized users.

Eva Leu

eva.leu@akvaplan.niva.no

1 Norwegian Polar Institute, FRAM Centre, 9296 Troms $\varnothing$, Norway

2 Present Address: Akvaplan-niva AS, CIENS, Gaustadalléen 21, 0349 Oslo, Norway

3 Alfred-Wegener-Institute, Helmholtz Centre for Polar and Marine Research, Am Handelshafen 12, 27570 Bremerhaven, Germany

4 Department of Biological and Environmental Sciences, University of Gothenburg, Box 461, 40530 Göteborg, Sweden diatoxanthin in all species ( $S$. hyperborea, Thalassiosira sp., Porosira glacialis) was higher in the $0.5 \mathrm{~m}$ exposure compared to $8 \mathrm{~m}$. In $S$. hyperborea, growth was additionally inhibited by UVR at $0.5-\mathrm{m}$ depth. In situ radiation conditions led, furthermore, to a significant decrease in polyunsaturated fatty acids (PUFAs) in all three species, but UVR had no additional effect. Hence, we conclude that natural radiation conditions close to the surface could reduce growth and PUFA concentrations, but the effects are species specific. The diatoms' potential to acclimate to these conditions over time has to be evaluated.

Keywords UVR · PAR · PUFA · Xanthophyll cycle · Arctic $\cdot$ Microalgae

\section{Introduction}

The rapid decrease in Arctic sea ice cover that has been observed during the most recent years (NSIDC 2011) leads to profound changes in the light conditions in Arctic marine ecosystems. Decreased sea ice thickness, less snow cover, and an earlier ice break-up during spring will result in higher ambient irradiances during algal spring blooms (Nicolaus et al. 2012). Also, the stratification of surface waters is supposed to increase, as a result of less saline and warmer surface waters (Strom and Fredrickson 2008). It is generally assumed that increased light availability will result in a higher annual primary production in this area (Sakshaug 2004; Arrigo et al. 2008; Pabi et al. 2008). However, high-irradiance levels can also induce oxidative stress (Foyer et al. 1994), decrease growth rates, induce defence mechanisms [synthesis of photoprotective pigments, see Brunet et al. (2011)], and affect the biochemical composition of algae (Thompson et al. 1990; 
Sterner and Elser 2002; Leu et al. 2006b, c). Microalgal primary producers in the Arctic comprise both sea ice algae, phytoplankton and microphytobenthos, and many of them are physiologically adapted to weak radiation (Sakshaug et al. 2009; von Quillfeldt et al. 2009). Hence, a sudden exposure to higher irradiances is potentially detrimental to them. Particularly dangerous might be ultraviolet radiation (UVR $280-400 \mathrm{~nm}$ ) due to its highenergetic potential shown to reduce growth and phytoplankton productivity (Smith et al. 1992; for reviews, see de Mora et al. 2000; Vernet 2000; Vincent and Neale 2000). In cold environments, these effects are expected to be more severe, as enzymatic repair is slower at low temperatures (Ross and Vincent 1998). UVR has been increasing due to seasonal events of depletion in the stratospheric ozone layer, and during the Arctic spring 2011, the Arctic ozone layer reached an all-time low, leading to what was called the first Arctic ozone hole ever (Manney et al. 2011). However, negative UVR effects on microalgae are not ubiquitous. For example, polar benthic pennate diatoms have been shown to be relatively tolerant to UVR (Zacher et al. 2007; Wulff et al. 2008), and species-specific or even strain-specific differences have to be expected. Concomitantly, irradiance (E) in the wavelength range of photosynthetically available radiation (PAR, 400-700 nm) increases in Arctic marine ecosystems as a consequence of decreasing ice cover. Evidence from both laboratory experiments and field studies point at a negative effect of high irradiances in the PAR spectrum on the relative amount of nutritionally valuable polyunsaturated fatty acids (PUFAs) in microalgae (Leu et al. 2006b, c, 2010), whereas a detrimental effect of UVR on PUFAs was not found in these studies. Several long-chain PUFAs are synthesized exclusively by marine algae (Ackman et al. 1968) and are essential to higher organisms that need to take them up through their diet (Harwood and Jones 1989; Sargent et al. 1995). PUFAs have been proven to be of major importance, especially during the key period of reproduction in spring (Pond et al. 1996; Jonasdottir et al. 2002) and are efficiently enriched in higher trophic levels (Falk-Petersen et al. 1990). Hence, even if an overall increase in light availability might indeed result in increased total annual primary production, the quality of the synthesized algal material could well be inferior to what is found today. A previous outdoor experimental study with another Arctic diatom species had proven a surprisingly quick response of algal fatty acid composition to high-irradiance exposure $(<24 \mathrm{~h})$, followed by a comparatively slow regeneration period (7-10 days) (Leu et al. 2006c). As quick responses to abrupt changes clearly are relevant in a dynamic environment like the (partly) sea ice-covered Arctic during spring, we designed the current study as short-term experiments in order to increase our understanding of the rapid responses.

Photosynthetic organisms have evolved a variety of mechanisms to handle high irradiances and, in particular preventing oxidative stress that is caused by induction of reactive oxygen species in association with photosynthesis. Central in these defence mechanisms is the production of so-called photoprotective pigments (for a review, see Brunet et al. 2011). These pigments are synthesized when algae experience stressful conditions and absorb partly the incoming excessive radiation energy, in order to protect the photosynthetic apparatus. In diatoms, excessive energy can be modulated through thermal dissipation by de-epoxidation of diadinoxanthin to diatoxanthin in the xanthophyll cycle (Olaizola and Yamamoto 1994; van de Poll et al. 2006; Wulff et al. 2008). Excessive irradiance also leads to a decrease in photosynthetic efficiency due to non-photochemical quenching of incoming radiation, and/or lasting photodamage (Hanelt 1998). Fluorescence-based measuring techniques allow to follow the photophysiological state of algae with a high-temporal resolution and to study their response towards environmental stress (Suggett et al. 2010). Diurnal changes in the maximum quantum yield of dark-acclimated cells, abbreviated as photosynthetic yield $F_{\mathrm{v}} / F_{\mathrm{m}}$, indicate during which periods the incoming irradiance exceeds the algal needs for powering photosynthesis, and whether or not the induced stress response is reversible or results in lasting damage.

The aim of this study was to test the short-term physiological response of Arctic diatoms to in situ irradiances close to the water surface, including the effect of UVR, as well as potential consequences for algal nutritional quality. We studied changes in cell numbers and chlorophyll a concentrations, and the response of defence mechanisms (composition and concentration of photoprotective pigments), together with fatty acid composition. For additional information, a diurnal cycle of photosynthetic yield under ambient conditions was measured with high-temporal resolution.

\section{Materials and methods}

The experiments were carried out during spring 2008 (April/May) in Kongsfjorden, close to Ny-Ålesund (Svalbard, Norway) at $79^{\circ} \mathrm{N}$ (Fig. 1). Unialgal diatom cultures isolated from the Svalbard archipelago were exposed to natural radiation conditions, with and without UVR, at 0.5 and $8-\mathrm{m}$ depths for $40 \mathrm{~h}$. Three different diatom species were studied: the centric pelagic species Porosira glacialis (Grunow) Jorgensen and Thalassiosira sp., and the pennate, sympagic (ice-associated) species, Synedropsis hyperborea (Grunow) G.R. Hasle, L.K. Medlin \& E.E. 


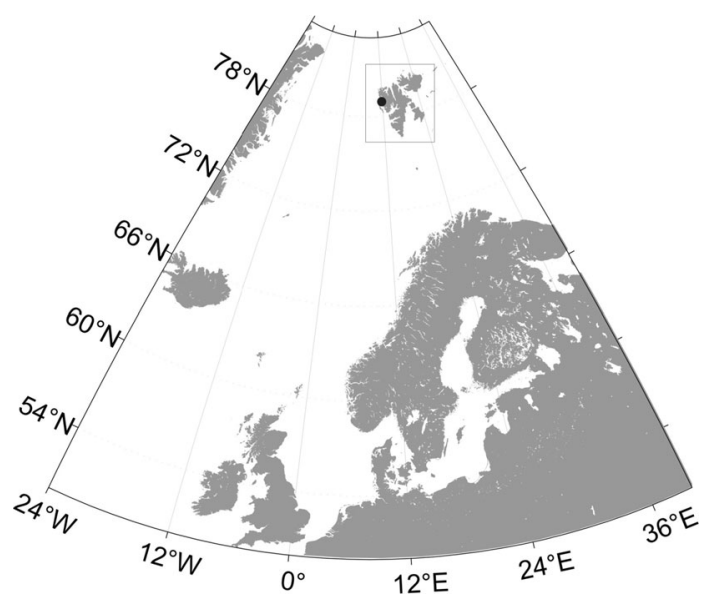

Fig. 1 Map over Northern Europe, indicating the location of Kongsfjorden (Svalbard, Norway) and the settlement Ny-Ålesund

Syvertsen. Before the experiments started, the algal cultures were kept for approximately two weeks in a culture room with constant temperature at $0.5{ }^{\circ} \mathrm{C}$ and $80 \mu \mathrm{mol}$ photons $\mathrm{m}^{-2} \mathrm{~s}^{-1}$ photosynthetic active radiation (PAR), provided by fluorescent tubes (OSRAM Lumilux de luxe $58 \mathrm{~W} / 950$ daylight) in a 16:8 h light/dark cycle. Double GF/F-filtered seawater enriched with nutrients in $\mathrm{f} / 10$ concentration (Guillard 1975) was used for cultivation. The diatom cultures were regularly diluted with fresh medium every 3-5 days, depending on cell density.

The experimental set-up was a modified version of a similar set-up used in the study by Wiencke et al. (2006),

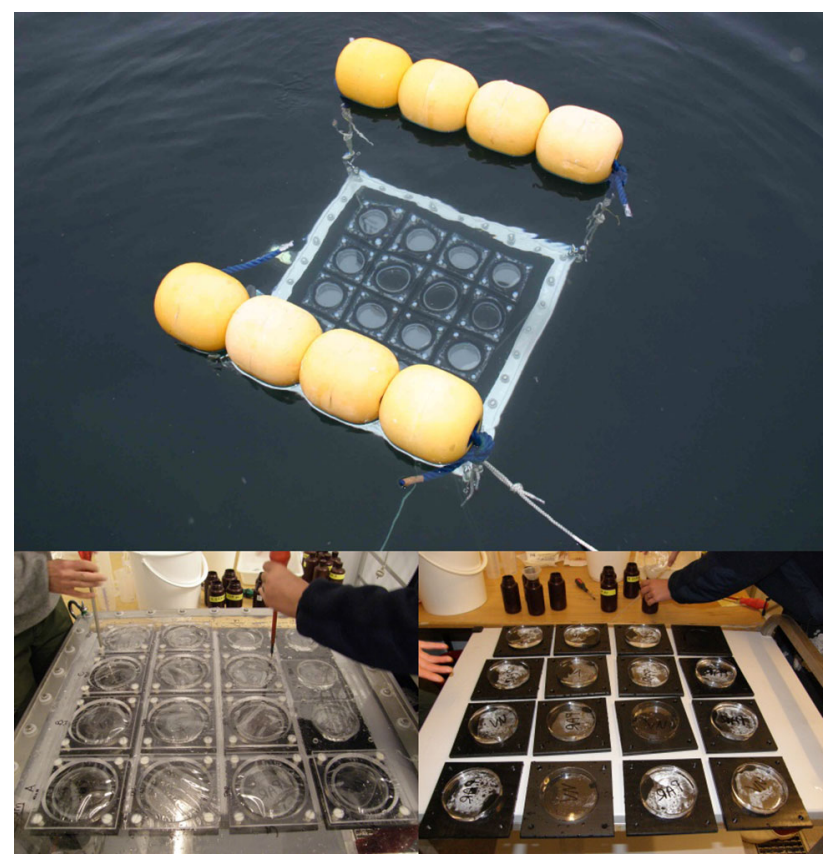

Fig. 2 Experimental set-up: aluminium frame at $0.5-\mathrm{m}$ depth with exposure dishes. Pictures by Eva Leu and Wojtek Moskal
Fig. 2. Sample holders for the field experiment consisted of UV-transparent Plexiglas "GS 2458" (Röhm, Darmstadt, Germany, mean transmission $93 \%$ of PAR $(400-700 \mathrm{~nm})$, $92 \%$ of UV-A $(320-400 \mathrm{~nm})$ and $86 \%$ of UV-B $(280-320 \mathrm{~nm}))$ in an aluminium frame $(0.8 \times 0.8 \mathrm{~m})$. Sixteen Petri dishes without lids $(94 \times 16 \mathrm{~mm}$, volume ca. $110 \mathrm{ml}$ ), arranged in a $4 \times 4$ grid, were mounted to the underside of these frames, with black plastic bottom squares underneath. Each treatment $(0.5$ and $8 \mathrm{~m}$, natural irradiance and without UVR) consisted of four replicates that were randomly distributed on the frame. Two frames were deployed at each depth, in order to be able to pool two Petri dishes from the same treatment to have a sufficient sample volume for all variables to be analysed. Each species was tested in a separate round of experiments, as only four frames were available (see Table 2). To investigate the effect of UVR, the Plexiglas above the Petri dishes was covered with Ultraphan 400 foil (Digefra, Munich, Germany), shielding half of the Petri dishes from UV radiation. The control Petri dishes were covered with cellulose acetate foil (Tamboer \& Co Chemie B.V., Heemstede, Netherlands) to correct for the ca. $10 \%$ absorption of Ultraphan 400 in the PAR spectrum. Transmission spectra of these two foils were published in Leu et al. (2007). To record the diurnal changes in irradiance, every frame was equipped with a HOBO light/temperature logger that recorded the in situ conditions during the entire experiment with 1-min resolution. On one of the frames at each depth, we mounted in addition a X2000/14 UV-dosimeter (Gigahertz Optik, Türkenfeld, Germany), measuring the UVA and UVB intensity and dose at the current depth (also every minute). In addition, vertical profiles of incoming radiation down to $45 \mathrm{~m}$ (integrated PAR) were measured repeatedly under different cloud conditions, and at different times of the day, using a cosine-corrected underwater quantum sensor (LI-192, LI-COR, Lincoln, Nebraska, USA), in combination with a surface reference sensor in air (LI-190, LI-COR, Lincoln, Nebraska, USA) measuring incident radiation at the ice surface. Diurnal changes in underwater irradiance at 2-m depth were recorded during a 60-h logging period with a hyperspectral UV/VIS irradiance sensor (320-950 nm, RAMSES-ACC-VIS, TriOS Mess- und Datentechnik, Rastede, Germany). The logging period included cloudless weather conditions for $>12 \mathrm{~h}$ (from min to max solar angle), followed by complete overcast (also covering the entire range of solar angles at that time of the year). Spectra were recorded every $30 \mathrm{~min}$.

Samples for counting cell numbers, and determining particulate carbon (PC), fatty acid and photosynthetic pigment composition were taken initially and at the end of the experimental exposure period. To allow the algae to acclimate smoothly to their new environment, experiments usually started during the evening (6-10 p.m. local time) 
and were terminated around $40 \mathrm{~h}$ later, during early afternoon, right after exposure to daily maximum irradiances. Outmost care was taken to minimize the time between frame retrieval from the water and sample filtration. Experimental frames were transported wrapped in black plastic bags.

\section{Cell numbers}

Initially and at the end of each experimental period, $5-10 \mathrm{ml}$ cell suspension from each replicate sample was fixated with Lugol's solution and stored in darkness until counting. For estimation of cell density, $1 \mathrm{ml}$ of a wellmixed sample was pipetted into a Sedgwick-Rafter counting chamber and a minimum of 300 cells were counted, however, always a minimum of 60 squares ( 1 square in the counting chamber $=1 \mu \mathrm{l}$ ). Due to low biomass of $P$. glacialis, for this species, a mean value of $400 \mu \mathrm{l}$ was counted.

\section{Photosynthetic pigments}

From each replicate, $30-50 \mathrm{ml}$ was filtered on separate $25 \mathrm{~mm} \mathrm{GF} / \mathrm{F}$ filters, the filters were frozen in liquid nitrogen, transferred to $-80{ }^{\circ} \mathrm{C}$ and analysed within 6 months. The filtered cells were extracted in $1.5 \mathrm{ml}$ $100 \%$ methanol. The extract was sonicated for $45 \mathrm{~s}$ using a ultra-sonicator (Vibra-cell) equipped with a $3 \mathrm{~mm}$ diameter probe operating at $80 \%$ in 5 s pulses (Wright and Jeffrey 1997). The extraction and HPLC analysis continued according to Wright and Jeffrey (1997) using an absorbance diode-array detector (SpectraphysicsUV6000LP). The column used was a $\mathrm{C}_{18}$ Phenomenex Ultracarb $3 \mu \mathrm{m}$ ODS (20) $(150 \mathrm{~mm} \times 3.20 \mathrm{~mm})$ equipped with a guard column, Security Guard Phenomenex $\mathrm{C}_{18}$ $(4 \mathrm{~mm} \times 3.0 \mathrm{~mm})$. The HPLC was calibrated with pigment standards from DHI Water and Environment, Denmark. Peak identities were further confirmed by online recording of absorbance spectra $(400-700 \mathrm{~nm}$ ) (Wright and Jeffrey 1997). Chlorophyll $a(\operatorname{chl} a)$ is expressed as $\mu \mathrm{g} 1^{-1}$ and to distinguish a possible physiological response to the treatments, pigment ratios (weight/weight) were determined; separate photosynthetic pigments to chl $a$, total carotenoids (fucoxanthin, diadinoxanthin, diatoxanthin and betacarotene) to chl $a$ and xanthophyll-cycle pigments (diatoxanthin/(diadinoxanthin plus diatoxanthin).

\section{Fatty acids}

Initially and at the end of the experiment, $80 \mathrm{ml}$ from each replicate was filtered on a pre-combusted $25-\mathrm{mm} \mathrm{GF} / \mathrm{F}$ filter and put into glass vials with $8 \mathrm{ml}$ dicholoromethane/ methanol $(2: 1, \mathrm{v} / \mathrm{v})$. They were stored at $-20{ }^{\circ} \mathrm{C}$ until analysis. Filters were then crushed by ultrasonification and extracted in dichloromethane/ methanol $(2: 1, \mathrm{v} / \mathrm{v})$ following the method after Folch et al. (1957). Prior to extraction, an internal standard was added (23:0 FAME). For gas liquid chromatography of fatty acids, methyl esters were prepared from aliquots of the extracted microalgae by transesterification with $3 \%$ sulphuric acid in methanol for $4 \mathrm{~h}$ at $80{ }^{\circ} \mathrm{C}$. After extraction with hexane, fatty acid methyl esters (FAME) were analysed with a gas-liquid chromatograph (Agilent 6890, Agilent GmbH, Waldbronn, Germany) on a capillary column $(60 \mathrm{~m} \times 0.25 \mathrm{~mm}$ I.D.; film thickness: $0.25 \mu \mathrm{m}$; liquid phase: DB-FFAP (Agilent) using temperature programming (53) (Injection: splitless at $250^{\circ}$, detection: FID at $280^{\circ} \mathrm{C}$ ). FAMEs were identified by comparison with known standard mixtures. If necessary, identification of FAMEs was confirmed by gas chromatography-mass spectrometry (GC-MS) measurements. Total lipid concentrations refer to the sum of total fatty acid methyl esters.

\section{UV-absorbing compounds}

To screen for the absence or presence of UV-absorbing compounds, we filtered $300 \mathrm{ml}$ of each culture (kept in the culture chamber-not from the experimental set-up) on $25-\mathrm{mm}$ GF/F filters. For extraction, $2 \mathrm{ml}$ of $25 \%$ methanol was added and the extraction proceeded in a water bath (ca $45^{\circ} \mathrm{C}$ ) for $2 \mathrm{~h}$. After extraction, the suspension was filtered through $0.45 \mu \mathrm{m}$ syringe filters and analysed in a Shimadzu UV-2401 spectrophotometer. To identify a possible absorbance in the UV range, an absorbance spectrum between 280 and $700 \mathrm{~nm}$ was recorded.

\section{Photosynthetic yield}

In order to test the response of algal photophysiology towards the diurnal changes in irradiance, we measured their photosynthetic yield during $24 \mathrm{~h}$ in a separate experiment. Photosynthetic yield $F_{\mathrm{v}} / F_{\mathrm{m}}$ was estimated by variable chlorophyll fluorescence measurements in photosystem II (PSII), $\left(F_{\mathrm{m}}-\mathrm{F}_{0}\right) / F_{\mathrm{m}}=F_{\mathrm{v}} / F_{\mathrm{m}}$, where $F_{\mathrm{m}}$ is maximum fluorescent yield and $F_{0}$ is fluorescent yield before the light pulse in a dark-acclimated state, with a WATER-PAM fluorometer (Walz Mess- und Regeltechnik, Effeltrich, Germany).

Due to the long handling time (30-45 $\mathrm{min})$ when retrieving the frames, it was not possible to combine the in situ experiments with measurements of photosynthetic efficiency. We therefore studied diurnal variation of the photosynthetic yield in a separate experiment where the diatoms were exposed for ambient radiation for $37 \mathrm{~h}$ in outdoor aquaria. Measurements of dark-acclimated (15 min) photosynthetic yield were taken at least every 
second hour during a period of $37 \mathrm{~h}$, with hourly resolution during the periods of major changes in $F_{\mathrm{v}} / F_{\mathrm{m}}$.

\section{Statistical analyses}

Treatment effects of the exposure to $40 \mathrm{~h}$ in situ irradiance conditions at 0.5 and $8 \mathrm{~m}$ with and without UVR, respectively, were tested by one-way ANOVA for the results from the four different treatments at the end of the experiment. Levene's test was used to check the data for homogeneity of variances, and a Kruskal-Wallis-test was applied in those cases where this criterion was not fulfilled. All analyses were performed with non-transformed data, using STATISTICA 7.0 (StatSoft Inc.).

\section{Results}

\section{Irradiance conditions during experiments}

PAR intensities measured in the air during the experimental period reached noon values up to $860 \mu \mathrm{mol} \mathrm{m}{ }^{-2}$ $\mathrm{s}^{-1}$ under cloudless conditions and $450 \mu \mathrm{mol}$ photons $\mathrm{m}^{-2} \mathrm{~s}^{-1}$ under overcast conditions. The daily minimum irradiances around midnight were around $140 \mu \mathrm{mol}$ photons $\mathrm{m}^{-2} \mathrm{~s}^{-1}$ without clouds (Table 1). Of these surface irradiances, about $70 \%$ were detected at the experimental depth of $0.5 \mathrm{~m}$, while $17-27 \%$ reached $8-\mathrm{m}$ depth (Table 1, Fig. 3). Due to variability of cloud cover, the integrated PAR doses for the three experiments were slightly different: while Synedropsis hyperborea experienced the lowest PAR dose, Thalassiosira sp., and Porosira glacialis received $105 \%$ and $116 \%$ of that, respectively. Total UV doses for the respective experiments ranged from $670 \mathrm{~kJ} \mathrm{~m}^{-2}$ (UVA) and $16.7 \mathrm{~kJ} \mathrm{~m}^{-2}$ (UVB) to $762 \mathrm{~kJ} \mathrm{~m}^{-2}$ (UVA) and $17.7 \mathrm{~kJ} \mathrm{~m}^{-2}$ (UVB) at 0.5-m depth (Table 2). Diurnal changes in UVR at 0.5 versus $8-\mathrm{m}$ depth are shown for the experiment with $S$. hyperborea in Fig. 4. Approximately $30 \%$ of the UVA radiation measured at $0.5 \mathrm{~m}$ was detected at $8 \mathrm{~m}$, while the ratio for UVB was only $10 \%$ due to more efficient absorption. Radiation conditions during the PAM

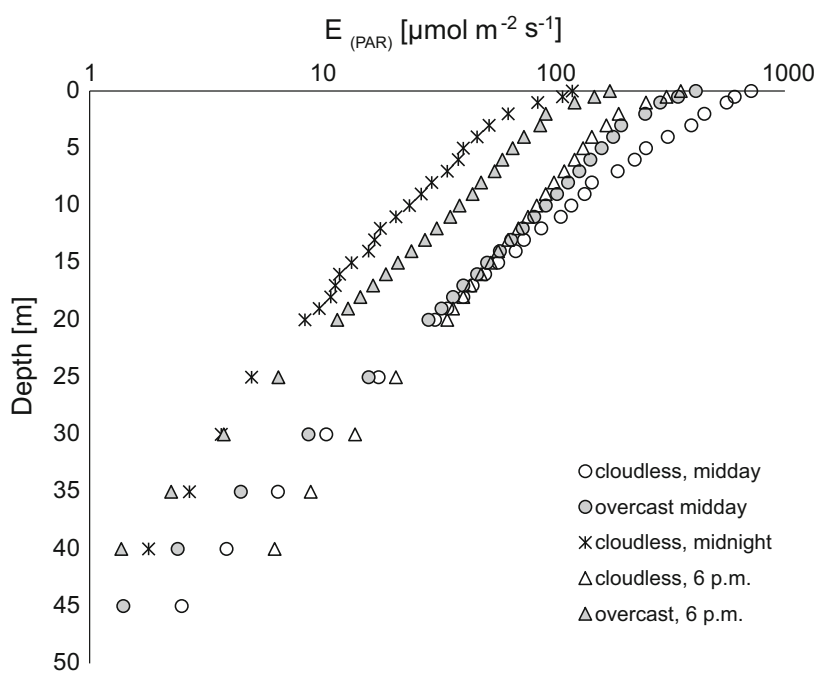

Fig. 3 Vertical underwater profiles PAR $\left(\mu \mathrm{mol} \mathrm{m} \mathrm{m}^{-2} \mathrm{~s}^{-1}\right)$ measured by a cos-corrected LICOR sensor at different times of the day under cloudless conditions (maximum values)

fluorometry diurnal measurement were comparable to the in situ exposure at $0.5-\mathrm{m}$ depth, as the weather was rather cloudy during this period (data not shown). During a period of $60 \mathrm{~h}$, the diurnal changes in the spectrum of incoming irradiance at 2-m depth were logged. Integrated PAR flux indicates a clear-sky period during the first half of this period (Fig. 5, inset), followed by overcast conditions; hourly changes in the spectral composition are shown in Fig. 5, with the upper panel (a, clear sky) corresponding to the period from solar noon to midnight on the 4 May, and the lower panel (b, overcast) covering the period from solar noon to midnight on the 5 May. Cloud cover absorbs more efficiently the longer wavelengths, and during the night period with a very low solar angle, the differences between clear sky and overcast conditions become very subtle.

\section{Cell numbers}

Initial total cell numbers $(n=4)$ were $1.0 \times 10^{7}(S$. hyperborea), $1.6 \times 10^{7}$ (Thalassiosira sp.) and for $P$. glacialis, $7.3 \times 10^{5}$ cells $\mathrm{L}^{-1}$ (Table 3 ). Statistically
Table 1 Irradiances (PAR) at surface, 8 and $0.5 \mathrm{~m}$ (measured during the first week of May 2008); integration time for all measurements: $30 \mathrm{~s}$

\begin{tabular}{|c|c|c|c|c|c|c|c|}
\hline & & \multicolumn{2}{|l|}{ Noon } & \multicolumn{2}{|l|}{6 p.m. } & \multicolumn{2}{|l|}{ Midnight } \\
\hline & & Cloudless & Overcast & Cloudless & Overcast & Cloudless & Overcast \\
\hline \multirow[t]{2}{*}{ Surface } & $\mu \mathrm{mol} \mathrm{m} \mathrm{m}^{-2} \mathrm{~s}^{-1}$ & 866 & 457 & 419 & 250 & 138 & n.a. \\
\hline & $\%$ & 100 & 100 & 100 & 100 & 100 & n.a. \\
\hline \multirow[t]{2}{*}{$0.5 \mathrm{~m}$} & $\mu \mathrm{mol} \mathrm{m} \mathrm{m}^{-2} \mathrm{~s}^{-1}$ & 608 & 346 & 309 & 151 & 100 & n.a. \\
\hline & $\%$ & 70 & 76 & 70 & 61 & 72 & n.a. \\
\hline \multirow[t]{2}{*}{$8 \mathrm{~m}$} & $\mu \mathrm{mol} \mathrm{m}{ }^{-2} \mathrm{~s}^{-1}$ & 147 & 116 & 101 & 49 & 30 & n.a. \\
\hline & $\%$ & 17 & 26 & 27 & 19 & 21 & n.a. \\
\hline
\end{tabular}


Table 2 Intensities $\left[\mathrm{W} \mathrm{m}{ }^{-2}\right.$ ] and doses $\left[\mathrm{kJ} \mathrm{m}^{-2}\right]$ of UVA (320-400 nm) and UVB (280-320 nm) radiation during the experiments, calculated from logged measurements at $0.5-\mathrm{m}$ depth

\begin{tabular}{|c|c|c|c|c|c|c|c|}
\hline Experiment & $\begin{array}{l}\mathrm{UVA}_{\min } \\
\left(\mathrm{W} \mathrm{m}^{-2}\right)\end{array}$ & $\begin{array}{l}\mathrm{UVA}_{\max } \\
\left(\mathrm{W} \mathrm{m}^{-2}\right)\end{array}$ & $\begin{array}{l}\mathrm{UVB}_{\min } \\
\left(\mathrm{W} \mathrm{m}^{-2}\right)\end{array}$ & $\begin{array}{l}\mathrm{UVB}_{\max } \\
\left(\mathrm{W} \mathrm{m}^{-2}\right)\end{array}$ & $\begin{array}{l}\text { Temperature } \\
\text { range }\left({ }^{\circ} \mathrm{C}\right)\end{array}$ & $\begin{array}{l}\text { Total dose } \\
\text { UVA }\left(\mathrm{kJ} \mathrm{m}^{-2}\right)\end{array}$ & $\begin{array}{l}\text { Total dose } \\
\text { UVB }\left(\mathrm{kJ} \mathrm{m}^{-2}\right)\end{array}$ \\
\hline $\begin{array}{l}\text { Synedropsis hyperborea } \\
\text { (29.4.-01.05.) }\end{array}$ & 0.85 & 11.47 & 0.009 & 0.30 & $1.4-3.2$ & 670 & 16.7 \\
\hline $\begin{array}{l}\text { Thalassiosira sp. } \\
(02 .-04.05 .)\end{array}$ & 1.80 & 10.56 & 0.025 & 0.31 & $1.5-3.2$ & 706 & 18.2 \\
\hline $\begin{array}{l}\text { Porosira glacialis } \\
\text { (06.-08.05.) }\end{array}$ & 1.20 & 12.95 & 0.013 & 0.29 & $1.6-3.4$ & 762 & 17.7 \\
\hline
\end{tabular}

Logging interval $1 \mathrm{~min}$
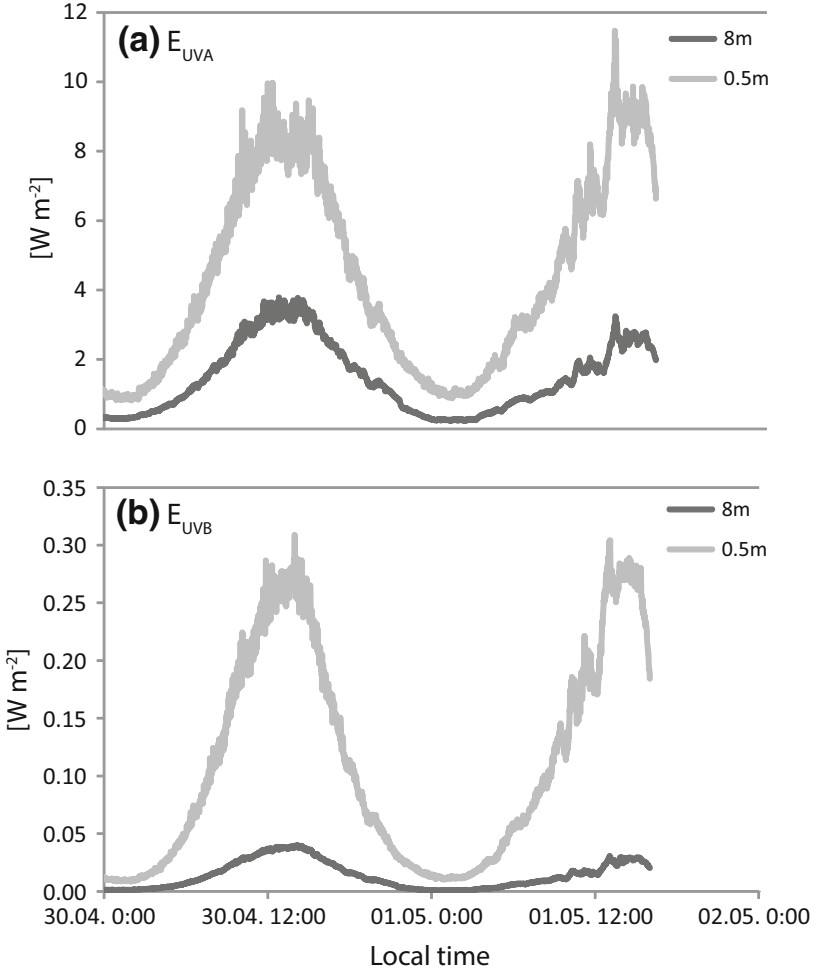

Fig. 4 Logged UVR intensities at 0.5- and 8-m depth, respectively, during one example experiment (Synedropsis hyperborea, 29.4.-1.5.), logging interval $1 \mathrm{~min}$, all values in $\mathrm{W} \mathrm{m}^{-2}$

significant depth effects were observed for S. hyperborea with lower cell numbers at $0.5 \mathrm{~m}$ compared with $8 \mathrm{~m}$ (Table 3). In addition, an UVR effect was found at $0.5-\mathrm{m}$ depth; lower cell number when exposed for UVR (Table 3). Compared with initial values, statistically significant reduced cell numbers were observed at $0.5-\mathrm{m}$ depth, both treatments. For Thalassiosira sp., depth effects were observed (cells numbers at $8 \mathrm{~m}>0.5 \mathrm{~m}$ ), but no significant UVR effects were found. Compared to initial cell concentrations, increased cell numbers were found for all depths and treatments. Porosira glacialis showed no statistically significant treatment effects at all (Table 3). Particulate carbon concentrations are provided in the appendix table (online resource 1). Only in Thalassiosira sp., carbon concentrations increased during the short experiment.

\section{Photosynthetic pigments and UV-absorbing compounds}

An overview of chl $a$ concentrations and ratios of photosynthetic pigments to chl $a$ are shown in the appendix table (online resource 1). When exposed to excessive radiation conditions, diatoms convert diadinoxanthin (Dd) to diatoxanthin (Dt), a process known as the xanthophyll cycle. For $S$. hyperborea, the ratio $(\mathrm{Dt} /(\mathrm{Dd}+\mathrm{Dt}))$ was higher at $0.5 \mathrm{~m}$ compared to $8-\mathrm{m}$ depth, both in the PAR and UVR treatment (Table 4). No UV-absorbing compounds were detected (data not shown). Also for Thalassiosira sp., depth effects were observed with higher ratios at $0.5 \mathrm{~m}$. In addition, an UVR effect was found with a higher ratio at $0.5-\mathrm{m}$ depth (Table 4). For UV-absorbing compounds (e.g. mycosporine-like amino acids), a small peak in the UV-range of the spectrum was observed. For $P$. glacialis depth effects in photosynthetic pigments were observed, again with higher ratios at $0.5 \mathrm{~m}$ compared with $8 \mathrm{~m}$ (Table 4). No effects of UVR were found. A clear peak in the UV-absorbance spectrum was found for $P$. glacialis, showing the presence of UV-absorbing compounds. Total carotenoid (here fucoxanthin, diadinoxanthin, diatoxanthin and betacarotene) to chl a ratios are considered an estimate of photoprotection when cells are exposed for excessive (potential harmful) radiation. For $S$. hyperborea, although the ratio was higher at $0.5 \mathrm{~m}$ compared with $8-\mathrm{m}$ depth, the effects were not statistically significant. For Thalassiosira sp., the ratios were higher at $0.5-\mathrm{m}$ depth with an additional UVR effect at $0.5 \mathrm{~m}$. Porosira glacialis showed depth effects $(0.5 \mathrm{~m}>8 \mathrm{~m})$, but no UVR effects (Table 5). 
Fig. 5 Diurnal changes in underwater spectral irradiance at 2-m depth during a cloudless and $\mathbf{b}$ complete overcast conditions. Plotted are one spectrum per hour, measured each hour at 13:23 to 01:23 $(\mathrm{UTC}+2)$. In the legend they are labelled with the nearest hour in local solar time, so that the sun was highest at 12 and lowest at 00. Insert Diurnal dynamics in integrated PAR measured at 2-m depth throughout the entire logging period of $60 \mathrm{~h}$ (3.-6. May 2008), including predominantly cloudfree conditions during the first part of the logging period, and overcast during the second part. Boxes indicate the periods from which data for plots $\mathbf{a}$ and $\mathbf{b}$ are taken
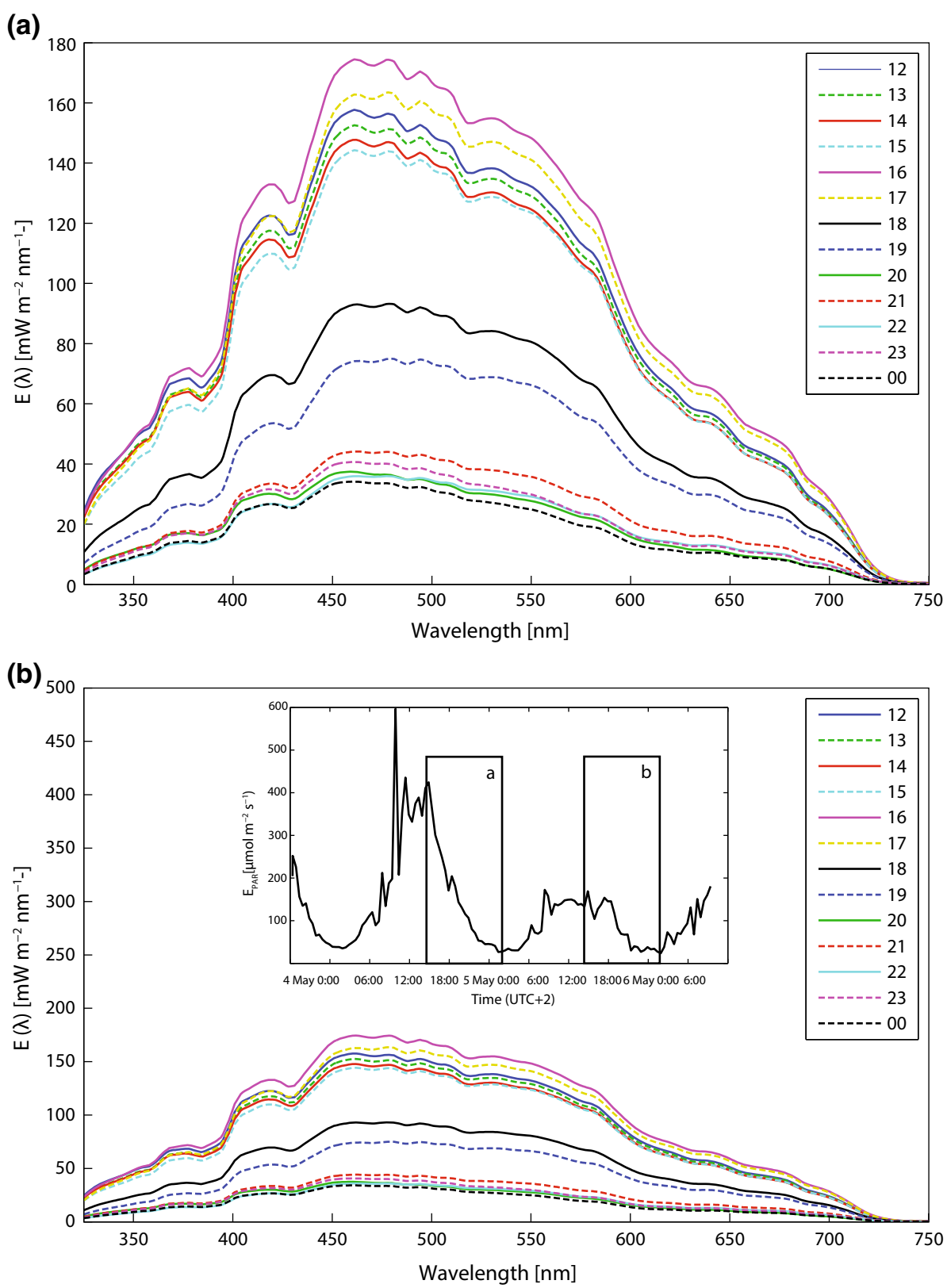

\section{Fatty acid composition}

In all experiments with all species, clear and significant changes of the initial fatty acid composition had occurred by the end of the experiment. In order to address the question whether irradiance in general or UVR in particular had an impact on diatom fatty acid composition, we focus on a comparison of the final fatty acid composition at the end of the experiment with the four different treatments PAR $0.5 \mathrm{~m}$, UVR $0.5 \mathrm{~m}$, PAR $8 \mathrm{~m}$ and UVR $8 \mathrm{~m}$, analysed by one-way ANOVA or Kruskal-Wallis test in cases where the homogeneity of variances was not given according to the Levene's test. The total lipid content relative to particulate carbon was calculated as the sum of all fatty acids (standardized to carbon). When comparing initial values with those in the four different treatments after the end of the experiment, only Synedropsis hyperborea showed a decrease in total fatty acids per carbon in three out of four treatments after the end of the experiment (Fig. 6). The sum of fatty acids per carbon in the algae exposed to PAR only at $0.5 \mathrm{~m}$ did not change compared to the initial value and was significantly higher than all other treatments.

Synedropsis hyperborea showed the most pronounced changes in fatty acid composition by the end of the experiment as compared to the initial conditions. While the 
Table 3 Cell numbers $\mathrm{L}^{-1} \times 10^{6}$ before (initial) and after treatment for each species, respectively $(n=4)$, with significant differences (s, $p<0.05$ ) and non-significant differences (ns) for depth effects, and radiation effects at different depths

\begin{tabular}{llll}
\hline & PAR & UVR \\
\hline $\begin{array}{l}\text { Synedropsis } \\
\text { hyperborea }\end{array}$ & & & \\
Initial 10.4(0.75) & & & \\
$0.5 \mathrm{~m}$ & $6.94(0.7)$ & $5.02(0.2)$ & $s$ \\
$8 \mathrm{~m}$ & $9.93(0.6)$ & $8.55(0.6)$ & $n s$ \\
& $s$ & $s$ & \\
Thalassiosira $\mathrm{sp}$. & & & \\
Initial 16.4(0.52) & & & \\
$0.5 \mathrm{~m}$ & $18.4(0.7)$ & $18.6(0.5)$ & $n s$ \\
$8 \mathrm{~m}$ & $20.5(0.2)$ & $22.6(1.5)$ & $n s$ \\
& $s$ & $s$ & \\
Porosira glacialis & & & \\
Initial 0.73(0.03) & & & $n s$ \\
0.5 m & & $0.62(0.05)$ & $n s$ \\
$8 \mathrm{~m}$ & $0.65(0.02)$ & & \\
& $0.76(0.02)$ & $0.74(0.03)$ & $n s$ \\
\end{tabular}

Treatments were ambient radiation conditions without UVR (PAR) and with UVR (UVR). Standard errors are shown within brackets
Table 5 The ratio of total carotenoids (fucoxanthin, diadinoxanthin, diatoxanthin, betacarotene) relative to chl a (weight/weight) before (initial) and after treatment for each species, respectively $(n=4)$

\begin{tabular}{llll}
\hline & PAR & UVR & \\
\hline $\begin{array}{llll}\text { Synedropsis hyperborea } \\
\text { Initial 1.15(0.05) }\end{array}$ & & \\
$0.5 \mathrm{~m}$ & $1.14(0.05)$ & $1.24(0.10)$ & $n s$ \\
$8 \mathrm{~m}$ & $1.10(0.02)$ & $1.03(0.07)$ & $n s$ \\
& $n s$ & $n s$ & \\
Thalassiosira sp. & & & \\
Initial 1.12(0.03) & & & \\
$0.5 \mathrm{~m}$ & $0.98(0.01)$ & $1.10(0.04)$ & $s$ \\
$8 \mathrm{~m}$ & $0.83(0.04)$ & $0.80(0.01)$ & $n s$ \\
& $s$ & $s$ & \\
Porosira glacialis & & & $n s$ \\
Initial 0.72(0.01) & & & \\
$0.5 \mathrm{~m}$ & $0.85(0.02)$ & $0.91(0.01)$ & $n s$ \\
$8 \mathrm{~m}$ & $0.80(0.00)$ & $0.79(0.00)$ & $n$ \\
& $s$ & $s$ &
\end{tabular}

Significant differences $(p<0.05, \mathrm{~s})$ and non-significant differences (ns) are shown for depth effects, and radiation effects at different depths. Treatments were ambient radiation conditions without UVR (PAR) and with UVR (UVR). Standard error is shown between brackets

decreased by about $15 \%$. The total PUFA content decreased from initially 38 to $30 \%$, with the lowest values found in the UVR treatments (Fig. 7a). There were, however, no statistically significant differences between the four treatments detectable by the end of the experiment (Table 6), probably indicating that even the exposure at $8 \mathrm{~m}$, and shielded from UVR was sufficient to cause the observed changes.

A similar pattern of change was found in Thalassiosira sp., with an increase in 16:0 by 30-40\% at the end of the experiment, and a concomitant reduction in polyunsaturated fatty acids, although weaker than in S. hyperborea (only $10-15 \%$, Fig. 7b). But in all major fatty acids, a statistically significant difference between the two depths of exposure was found by the end of the experiment, whereas no UV effect on the fatty acid composition was visible (see Table 6). Again, 16:0 was higher in algal cultures exposed at $0.5 \mathrm{~m}$ as compared to $8 \mathrm{~m}$, while all PUFAs were found in lower percentages at $0.5 \mathrm{~m}$. The major monounsaturated fatty acid 16:1n 7 accounting for $40 \%$ of total fatty acids in this species was the only exception to this general trend: although it was reduced by the end of the experiment as compared to the initial conditions, it was found in higher values at $0.5 \mathrm{~m}$ than at $8 \mathrm{~m}$ (Fig. 7b). 

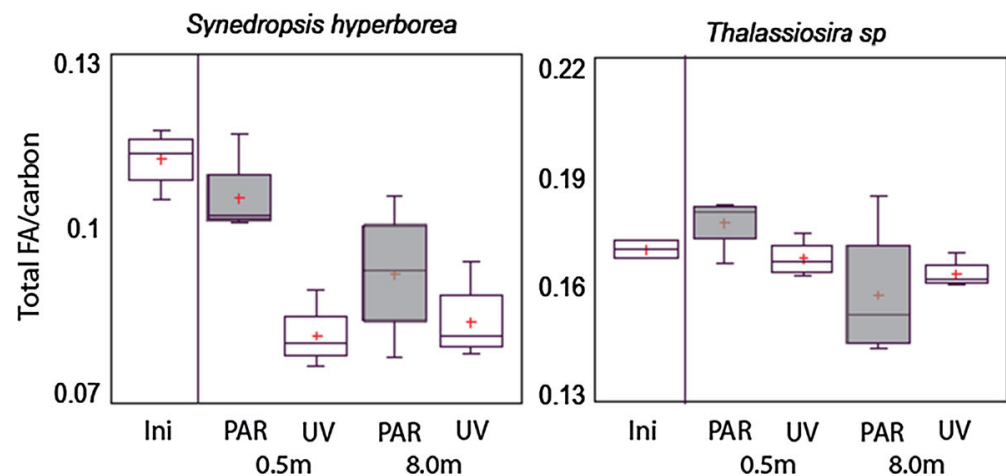

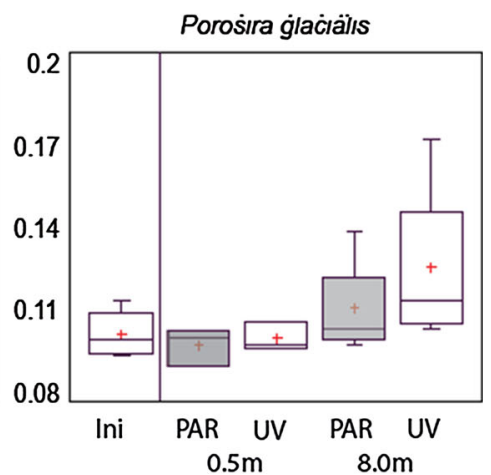

Fig. 6 Box whisker plots showing changes in total lipids after the experiments (given as sum of fatty acids per particulate carbon): Synedropsis hyperborea (a), Thalassiosira sp. (b), Porosira glacialis (c) $(n=4)$. Each box plot shows the middle $50 \%$ of the data, the
$25 \%$ quartile, median (horizontal line), $75 \%$ quartile, and mean value (red cross). Whiskers indicate the ranges for the maximum and minimum values

were similar for all three diatom species, although speciesspecific differences in both sensitivity and protective potential were found. Reductions in cell number and percentage of PUFAs were in all experiments caused mainly by high-PAR irradiances, while UVR played a minor role. This was manifested in significant differences between the algal cells exposed at $8 \mathrm{~m}$ compared to $0.5-\mathrm{m}$ depth, together with a lack of significant differences between UVR and PAR treatments at the same depth. The physiologically important polyunsaturated fatty acids were reduced in all species compared to their start conditions, and in two of three species, we found higher values at $8 \mathrm{~m}$ than at $0.5 \mathrm{~m}$. This is in line with previous studies about the detrimental effect of high-PAR irradiances on algal PUFAs (Leu et al. 2006b, c; 2010). Leu et al. (2006c) found rapid changes in the biochemical composition of another Arctic diatom culture Thalassiosira antarctica var. borealis after exposing it to ambient irradiances with and without UVR in outdoor aquaria. This experiment was carried out in $\mathrm{Ny}$ Ålesund over 17 days, and proved that the diatom culture was capable to acclimate to the outdoor irradiances and regained its original biochemical characteristics approximately after 10-12 days. The current study, however, describes for the first time these effects under experimental conditions in situ, confirming that the irradiances found at these latitudes still are sufficient to be potentially detrimental for essential PUFAs in algae. These important biomolecules cannot be synthesized de novo by higher organisms and are enriched efficiently in the food chain. Hence, changes in the amount of PUFAs in algae have the potential to exert cascading effects on higher trophic levels. Of the three studied species, Synedropsis hyperborea, the pennate sea ice algae, showed the strongest overall reduction of PUFAs between start and end of the experiment; no significant differences between the four different treatments were found in this species, indicating that 


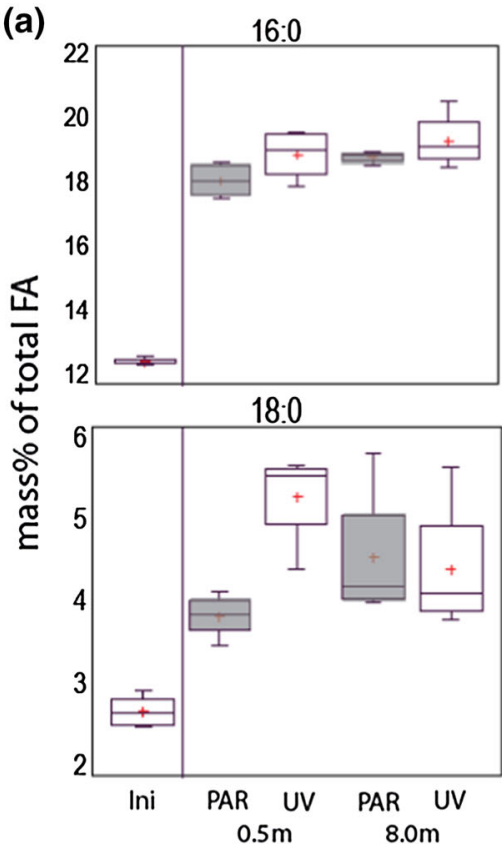

Synedropsis hyperborea

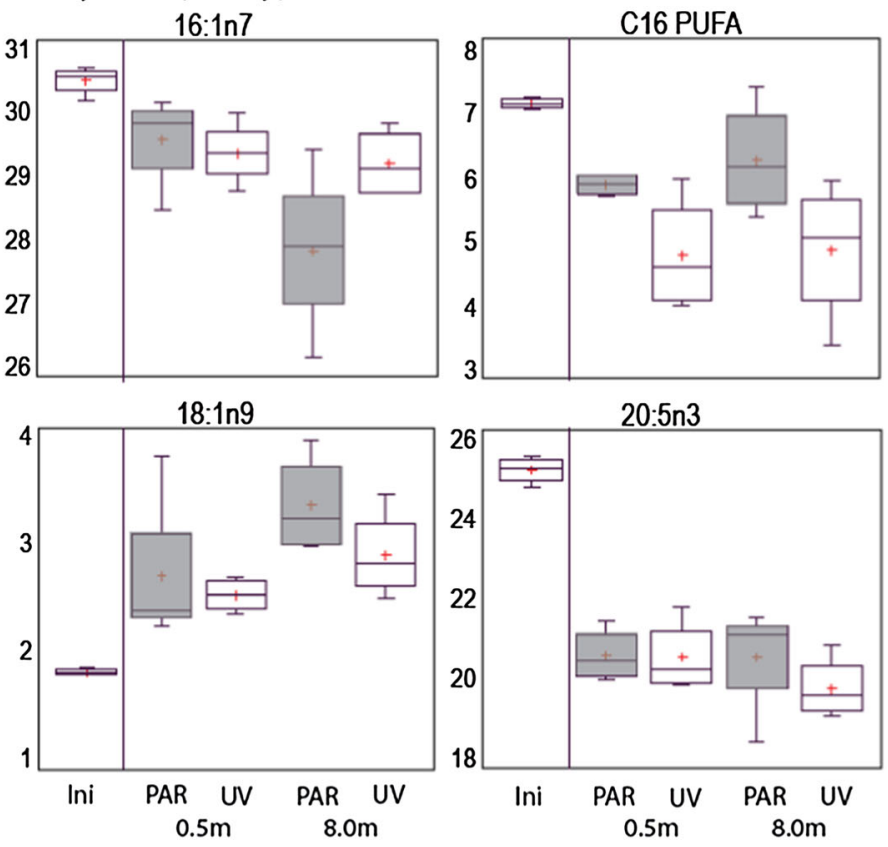

(b)

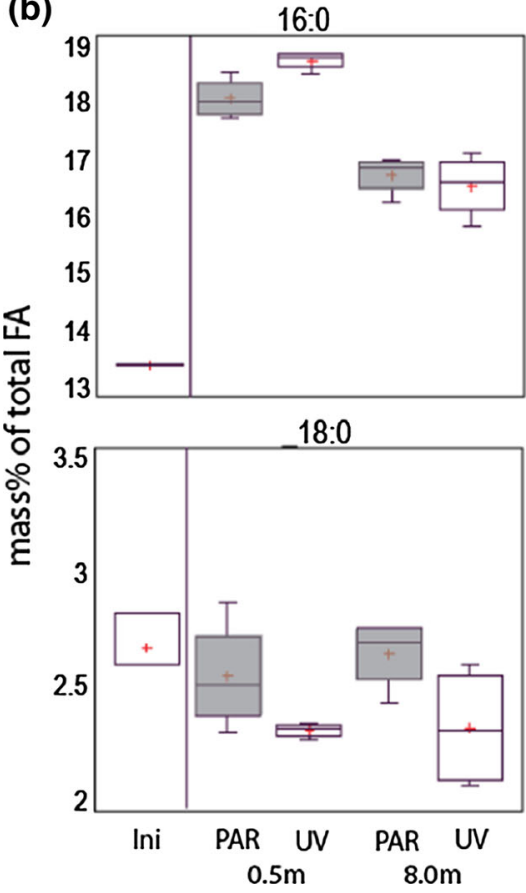

Thalassiosira sp.
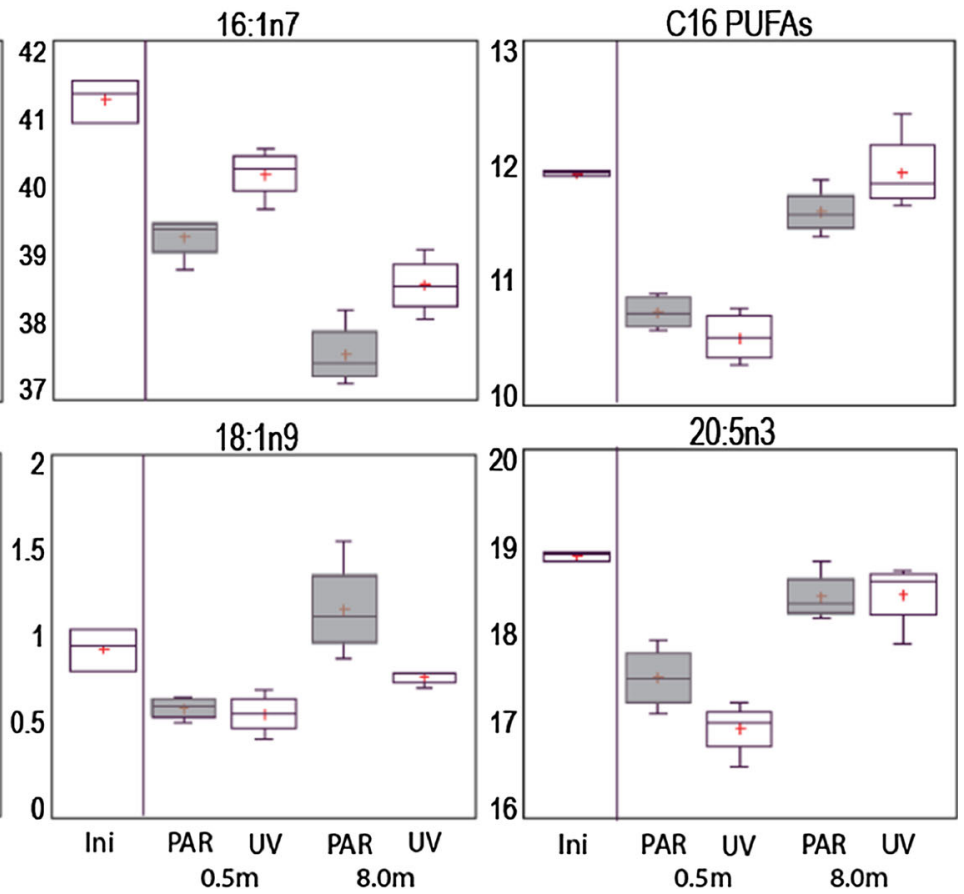

Fig. 7 Box whisker plots showing changes in most important fatty acids throughout the experiments with previous outdoor acclimation (given as percentage of total fatty acids): Synedropsis hyperborea (a), Thalassiosira sp. (b), Porosira glacialis $(\mathbf{c})(n=4)$. Shown are the initial values measured in the cultures prior to in situ exposure (ini), as well as fatty acid levels after $40 \mathrm{~h}$ of exposure at $0.5-$ and $8-\mathrm{m}$

already the exposure without UVR at $8 \mathrm{~m}$ was sufficient to cause the observed biochemical changes. The clearest differences between diatoms exposed at 0.5 versus $8-\mathrm{m}$ depth, respectively, and with (white boxes) and without UVR (grey boxes). Each box plot shows the middle $50 \%$ of the data, the $25 \%$ quartile, median (horizontal line), $75 \%$ quartile, and mean value (red cross). Whiskers indicate the ranges for the maximum and minimum values

depth were found in Thalassiosira sp., a small $(<10 \mu \mathrm{m}$ cell size) centric diatom. The third species, Porosira glacialis, had the highest PUFA content (up to $50 \%$ of total 
(c)

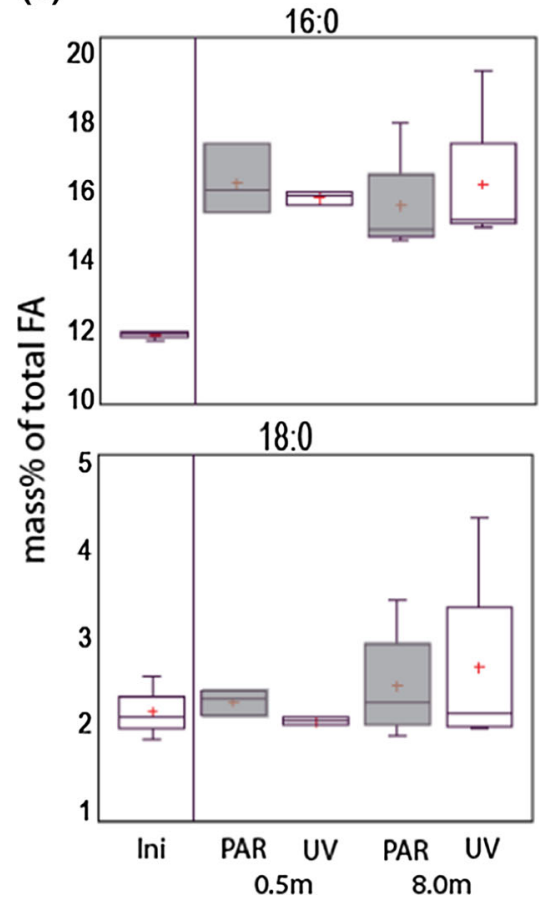

Porosira glacialis
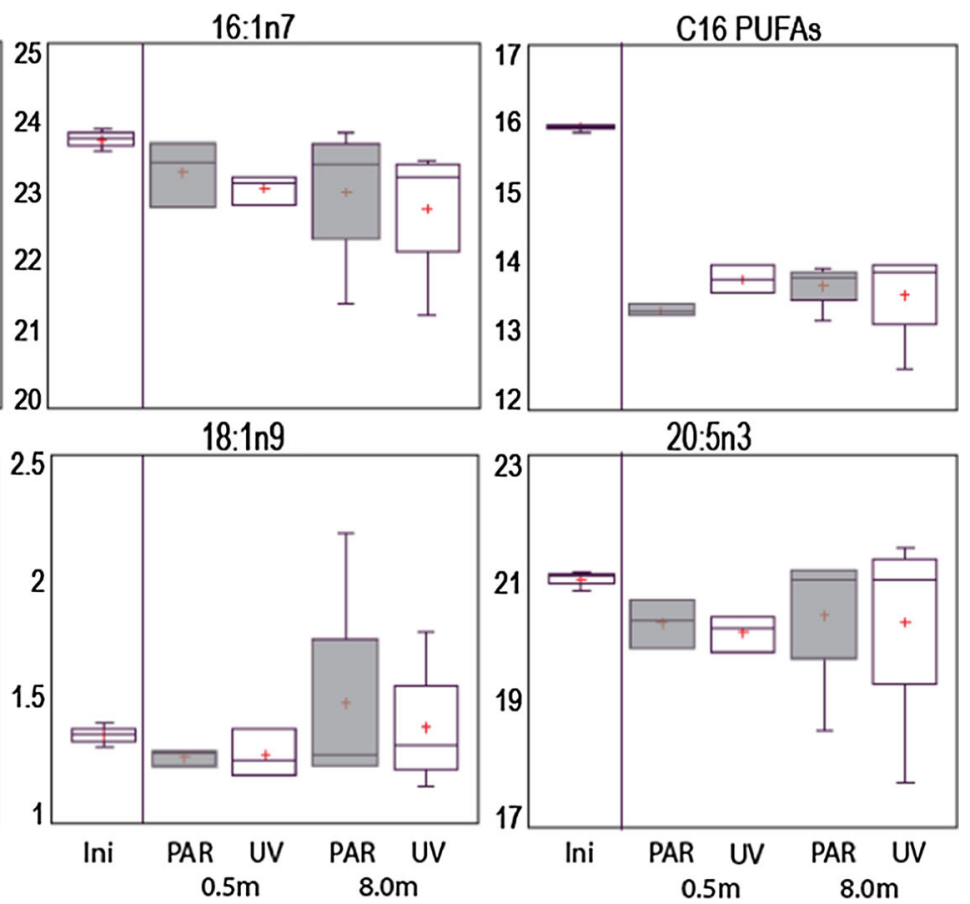

Fig. 7 continued

Table 6 Overview over results from statistical analyses of fatty acid composition differences between treatments after the end of the experiments (percentage data)

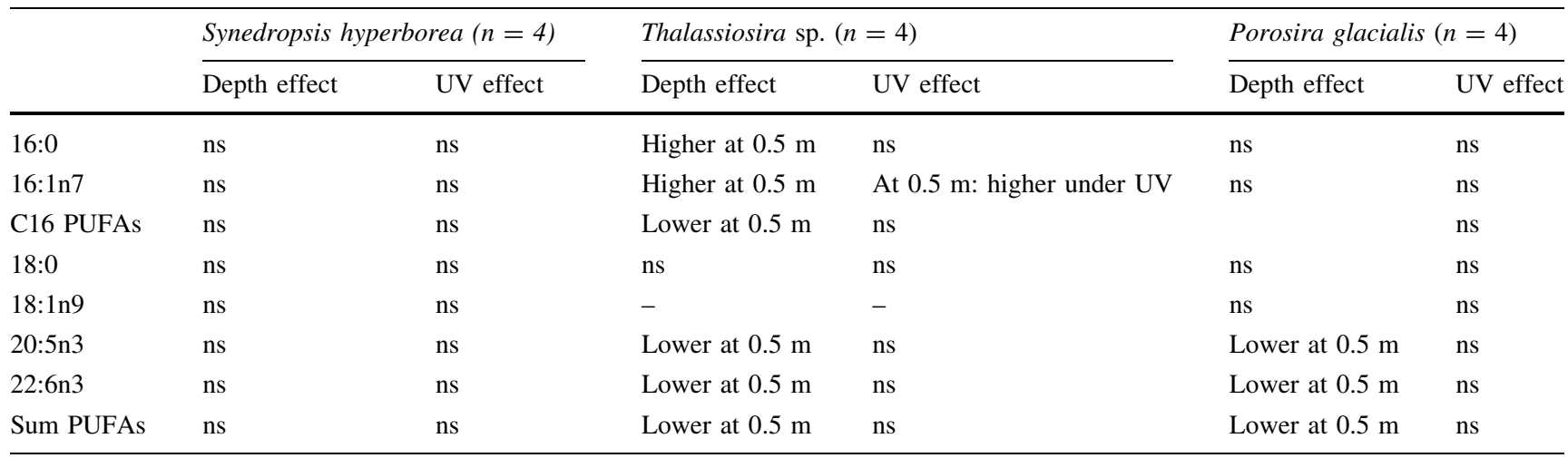

Shown are results from one-way ANOVA or Kruskal-Wallis test (in cases where homogeneity of variances was not given according to Levene's test). Depth effect indicates a significant difference between 0.5 and $8 \mathrm{~m}$ exposure, UVR effect indicates a significant difference between UVR and PAR treatment at the same depth

FAs), but showed only a moderate reduction of $\mathrm{C} 16$ PUFAs, while 20:5n3 and 22:6n3, the most important omega 3 fatty acids, were not significantly affected by the treatments. The lack of a negative effect of UVR on the percentage of PUFAs confirms also findings from previous laboratory experiments with three different species of Arctic diatoms (Leu et al. 2007) and one temperate chlorophyte (Leu et al. 2006a). Ambient temperatures during the in situ experiment were slightly higher and fluctuating compared to the pre-cultivation phase in the laboratory. However, if the observed effects were primarily caused by changes in temperature, no differences between the applied irradiance treatments should have been observed. With respect to cell numbers, higher temperatures should have led to higher numbers, which was not observed.

Our results showed overall clear species-specific differences in the diatoms' responses to the exposure to high 


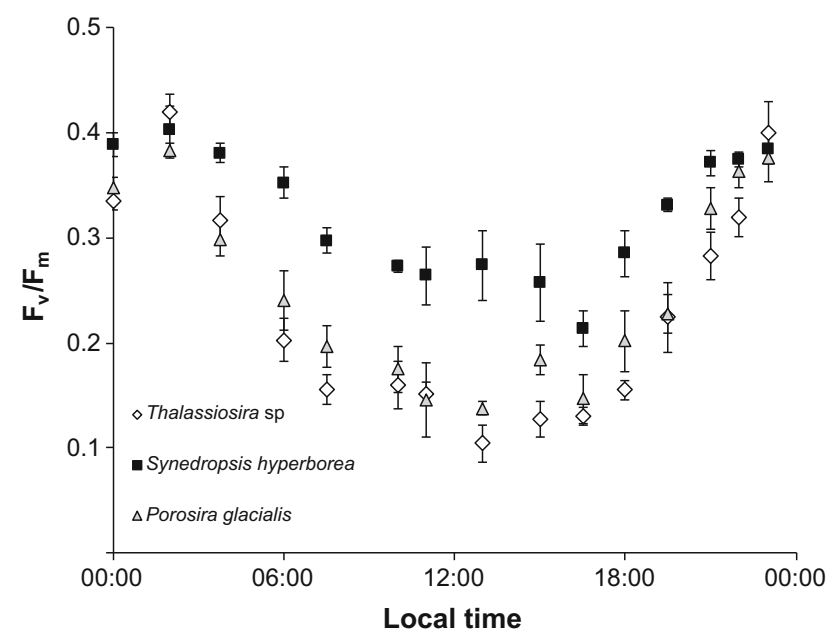

Fig. 8 Diurnal changes in dark-acclimated maximum quantum yield $\left(F_{\mathrm{v}} / F_{\mathrm{m}}\right)$ in all three diatom species (mean $\left.\pm \mathrm{SD}, n=4\right)$

irradiances with and without UVR. The underlying reasons for these differences can probably be explained by differences in the single species' strategy where to allocate most energy. Growth (increase in cell number) indicates a net positive balance of this strategy, but can still be far from the optimal conditions. We chose to use cell numbers and not chl a as a measure of biomass because it is a wellknown fact that cellular chl a concentrations can change rapidly in response to shifting radiation conditions (e.g. Falkowski and LaRoche 1991). Compared to initial conditions, cell numbers of $S$. hyperborea were reduced both with respect to PAR and UVR exposure, while Thalassiosira sp., showed higher cell numbers in all treatments but with different impact (only depth effects were observed). Least affected was $P$. glacialis, showing no significant differences between any of the applied treatments. Apart from being very large (which probably protects this species better from radiation stress than e.g. the much smaller Thalassiosira) (cf. Garcia-Pichel 1994), we also detected in this species the highest amount of UVabsorbing compounds, probably mycosporine-like amino acids (MAAs) (Jeffrey et al. 1999).

When exposed to high radiation (energy), the diatom xanthophyll cycle can modulate excessive energy through thermal dissipation, i.e. de-epoxidation of diadinoxanthin (Dd) to diatoxanthin (Dt) (Olaizola and Yamamoto 1994). It is unclear, however, if the activity of the xanthophyll cycle prevents UVR stress in microalgae (Buma et al. 2009). For all three species, the xanthophyll-cycle pigments offered potential protection at higher irradiances (shallower depths), and an increased ratio in Dt/(Dt $+\mathrm{Dd})$ with UVR exposure was found for Thalassiosira sp., at $0.5 \mathrm{~m}$. Similar findings (increased de-epoxidation under UVR) was observed for Thalassiosira weissflogii (Buma et al. 2009) and Phaeodactylum tricornutum (Goss et al. 1999). Sobrino et al. (2005) concluded that for the marine picoplankter Nannochloropsis gaditana (Eustigmatophyceae), de-epoxidation was mainly related to protection from excess PAR, and the UVR response was secondary. Dimier et al. (2007), hypothesized that the capacity of short-term pigment variations depends on the ecological characteristics of the species; short-term photoresponse being more often activated in highly mixed water columns than in more hydrodynamically stable ecosystems. Similar suggestions have also been proposed by Lavaud et al. (2007). While the de-epoxidation reaction occurs over minutes (Olaizola and Yamamoto 1994), the relative increase in total carotenoids to $\mathrm{chl}$ a (car/chl a) is probably a much slower process. Interestingly, also car/chl a showed depth effects over our $40 \mathrm{~h}$ experiments although not statistically significant for $S$. hyperborea. Carbon assimilation is not necessarily protected from UVR through the deepoxidation process (Buma et al. 2009), and in our study, it is indicated that it does not always protect against excessive PAR; despite significantly higher ratio of (Dt/ $(\mathrm{Dt}+\mathrm{Dd})$ and car/chl a, an irradiance (depth) effect was still found for both $S$. hyberborea and Thalassiosira sp., with more cells at $8 \mathrm{~m}$ compared to $0.5-\mathrm{m}$ depth. Also, with respect to their fatty acid composition $P$. glacialis seemed least affected from the applied exposure, compared to the other two species. Diurnal changes in maximum quantum yield were found in all three species, with a typical mid-day depression during highest solar elevation (Falkowski and Raven 1997). However, while algae at lower latitudes usually experience a dark night where potential photodamage can be repaired, they are exposed to continuous light at high latitudes during summer. In accordance with the results by Schofield et al. (1995), the recovery started already during the afternoon. The highest maximum quantum yield was measured shortly after the lowest solar angle and was similar in all three species (about 0.4). The decrease in photosynthetic yield during exposure to increasing irradiances, however, showed that the pennate diatom Synedropsis hyperborea had a less dynamic response compared to the two centric species and maintained a significantly higher maximum quantum yield during mid-day photoinhibition $(0.28$ vs. 0.12$)$. Photoinhibition occurs when the rate of excitation absorbed by reaction centres exceeds the rate of photochemistry. The latter is limited by the rate of electron transport components to Rubisco, and is, hence, temperature dependent (Falkowski and Raven 1997). Although the diatoms in our experiments were exposed to similar intensities and doses, we cannot rule out that the observed responses towards the experimental treatment have been affected by natural variations of the radiation conditions during the different experimental periods. 
The responses of the three different diatom species towards the exposure to natural irradiance conditions in high-Arctic surface waters were very consistent, indicating that both the induction of defence mechanisms and biochemical changes as a consequence to high-light exposure are similar, and occurring on very short time scales (compared to the generation time of these species at low temperatures). We also found strong species-specific differences, with the pennate sea-ice diatom Synedropsis hyperborea showing the strongest response, and the large centric diatom Porosira glacialis being least affected. Due to the short duration of this experiment, we cannot draw conclusions about long-term responses and adaptation potential. But it is probably reasonable to assume that there will be species-dependent differences in those as well. Hence, the changing Arctic light climate that accompanies the ongoing decrease in sea ice thickness has the potential to change the composition of microalgal communities, their growth and biochemical composition based on their photophysiological characteristics. Although not studied here, such alterations have the potential to cause indirect effects on grazers and other higher trophic levels as well.

Acknowledgments We are very grateful for the invaluable support by Wojtek Moskal during the fieldwork. Furthermore, we thank very much Christian Wiencke for lending us the frames used for the in situ exposure experiments and to Max Schwanitz for practical advices about their installation. Water-tight boxes for the UV loggers were built at the workshop at the Biological Institute, University of Oslo. Particulate carbon analyses were performed by Berit Kaasa. A thanks goes also to Stephen Hudson who helped plotting the spectral irradiance data. This study was funded as part of the CLEOPATRAproject by the Norwegian Research Council (Project nr. 178766/S30) as part of the Norwegian contribution to the International Polar Year (2007-2009).

\section{References}

Ackman RG, Tocher CS, McLachlan J (1968) Marine phytoplankter fatty acids. J Fish Res Board Can 25:1603-1620

Arrigo KR, van Dijken G, Pabi S (2008) Impact of a shrinking Arctic ice cover on marine primary production. Geophys Res Lett. doi: $10.1029 / 2008 \mathrm{~g} 1035028$

Brunet C, Johnsen G, Lavaud J, Roy S (2011) Pigments and photoacclimation processes. In: Roy S, Llewellyn CA, Egeland ES, Johnsen G (eds) Phytoplankton pigments: characterization, chemotaxonomy, and application in oceanography. Cambridge University Press, Cambridge, pp 445-471

Buma AGJ, Visser RJW, Van De Poll WH, Villafane VE, Janknegt PJ, Walter Helbling E (2009) Wavelength-dependent xanthophyll cycle activity in marine microalgae exposed to natural ultraviolet radiation. Eur J Phycol 44:515-524. doi:10.1080/ 09670260902971894

de Mora SJ, Demers S, Vernet M (eds) (2000) The effects of UV radiation in the marine environment vol 10. Cambridge Environmental Chemistry series, 1st edn. Cambridge University Press, Cambridge
Dimier C, Corato F, Tramontano F, Brunet C (2007) Photoprotection and xanthophyll-cycle activity in three marine diatoms. J Phycol 43:937-947. doi:10.1111/j.1529-8817.2007.00381.x

Falkowski PG, LaRoche J (1991) Acclimation to spectral irradiance in algae. J Phycol 27:8-14

Falkowski PG, Raven JA (1997) Aquatic photosynthesis. Blackwell Science, Massachusetts

Falk-Petersen S, Hopkins CCE, Sargent JR (1990) Trophic relationships in the pelagic, arctic food web. In: Barnes M, Gibson RN (eds) 24th European marine biology symposium, Aberdeen University Press, pp 315-333

Folch J, Lees M, Sloane Stanley GH (1957) A simple method for isolation and purification of total lipids from animal tissue. J Biol Chem 226:497-509

Foyer CH, Lelandais M, Kunert KJ (1994) Photooxidative stress in plants. Physiol Plant 92:696-717

Garcia-Pichel F (1994) A model for internal self-shading in planktonic organisms and its implications for the usefulness of ultraviolet sunscreens. Limnol Oceanogr 39:1704-1717

Goss R, Mewes H, Wilhelm C (1999) Stimulation of the diadinoxanthin cycle by UV-B radiation in the diatom Phaeodactylum tricornutum. Photosynth Res 59:73-80

Hanelt D (1998) Capability of dynamic photoinhibition in Arctic macroalgae is related to their depth distribution. Mar Biol 131:361-369

Harwood JL, Jones AL (1989) Lipid metabolism in algae advances in botanical research incorporating. Adv Plant Pathol 16:1-53

Jeffrey SW, MacTavish HS, Dunlap WC, Vesk M, Groenewoud K (1999) Occurrence of UVA- and UVB-absorbing compounds in 152 species (206 strains) of marine microalgae. Mar Ecol Prog Ser 189:35-51

Jonasdottir SH, Gudfinnsson HG, Gislason A, Astthorsson OS (2002) Diet composition and quality for Calanus finmarchicus egg production and hatching success off south-west Iceland. Mar Biol 140:1195-1206

Lavaud J, Strzepek RF, Kroth PG (2007) Photoprotection capacity differs among diatoms: possible consequences on the spatial distribution of diatoms related to fluctuations in the underwater light climate. Limnol Oceanogr 52:1188-1194

Leu E, Faerovig PJ, Hessen DO (2006a) UV effects on stoichiometry and PUFAs of Selenastrum capricomutum and their consequences for the grazer Daphnia magna. Freshw Biol 51:2296-2308

Leu E, Falk-Petersen S, Kwasniewski S, Wulff A, Edvardsen K, Hessen DO (2006b) Fatty acid dynamics during the spring bloom in a High Arctic fjord: importance of abiotic factors versus community changes. Can J Fish Aquat Sci 63:2760-2779

Leu E, Wangberg SA, Wulff A, Falk-Petersen S, Orbaek JB, Hessen DO (2006c) Effects of changes in ambient PAR and UV radiation on the nutritional quality of an Arctic diatom (Thalassiosira antarctica var. borealis). J Exp Mar Biol Ecol 337:65-81

Leu E, Falk-Petersen S, Hessen DO (2007) Ultraviolet radiation negatively affects growth but not food quality of arctic diatoms. Limnol Oceanogr 52:787-797

Leu E, Wiktor J, Søreide JE, Berge J, Falk-Petersen S (2010) Increased irradiance reduces food quality of sea ice algae. Mar Ecol Prog Ser 411:49-60

Manney GL et al (2011) Unprecedented Arctic ozone loss in 2011. Nature 478:U469-U475. doi:10.1038/nature10556

Nicolaus M, Katlein C, Maslanik J, Hendricks S (2012) Changes in Arctic sea ice result in increasing light transmittance and absorption. Geophys Res Lett. doi:10.1029/2012g1053738

Olaizola M, Yamamoto HY (1994) Short-term response of the diadinoxanthin cycle and fluorescence yield to high irradiance in Chaetoceros muelleri (Bacillariophyceae). J Phycol 30:606-612. doi:10.1111/j.0022-3646.1994.00606.x 
Pabi S, van Dijken GL, Arrigo KR (2008) Primary production in the Arctic Ocean, 1998-2006. J Geophys Res Oceans. doi:10.1029/ $2007 \mathrm{jc} 004578$

Pond D, Harris R, Head R, Harbour D (1996) Environmental and nutritional factors determining seasonal variability in the fecundity and egg viability of Calanus helgolandicus in coastal waters off Plymouth, UK. Mar Ecol Prog Ser 143:45-63

Ross JC, Vincent WF (1998) Temperature dependence of UV radiation effects on Antarctic cyanobacteria. J Phycol $34: 118-125$

Sakshaug E (2004) Primary and secondary production in the Arctic Seas. In: Stein R, Macdonald RW (eds) The organic carbon cycle in the Arctic Ocean. Springer, Berlin, pp 57-82

Sakshaug E, Johnsen G, Kristiansen S, von Quillfeldt C, Rey F, Slagstad D, Thingstad F (2009) Phytoplankton and primary production. In: Sakshaug E, Johnsen G, Kovacs K (eds) Ecosystem Barents Sea. Tapir Academic Press, Trondheim, pp 167-208

Sargent J, Bell MV, Bell JG, Henderson RJ, Tocher DR (1995) Origins and functions of n-3 polyunsaturated fatty acids in marine organisms. In: Cevc G, Paltauf F (eds) Phospholipids: characterization, metabolism and novel biological applications, pp 248-259

Schofield O, Kroon BMA, Prézelin BB (1995) Impact of ultraviolet-B radiation on photosystem II activity and its relationship to the inhibition of carbon fixation rates for antarctic ice algae communities. J Phycol 31:703-715

Smith RC et al (1992) Ozone depletion: ultraviolet radiation and phytoplankton biology in Antarctic waters. Science 255:952-959. doi:10.1126/science. 1546292

Sobrino C, Neale PJ, Montero O, Lubian LM (2005) Biological weighting function for xanthophyll de-epoxidation induced by ultraviolet radiation. Physiol Plantarum 125:41-51. doi:10.1111/ j.1399-3054.2005.00538.x

Sterner RW, Elser JJ (2002) Ecological stoichiometry. Princeton University Press, Princeton

Strom SL, Fredrickson KA (2008) Intense stratification leads to phytoplankton nutrient limitation and reduced microzooplankton grazing in the southeastern Bering Sea. Deep Sea Res II Top Stud Oceanogr 55:1761-1774. doi:10.1016/j.dsr2.2008.04.008

Suggett DJ, Borowitzka MA, Prášil O (eds) (2010) Chlorophyll a fluorescence in aquatic sciences: methods and applications. Springer, Netherlands
Thompson PA, Harrison PJ, Whyte JNC (1990) Influence of irradiance on the fatty acid composition of phytoplankton. J Phycol 26:278-288

van de Poll WH, Alderkamp AC, Janknegt PJ, Roggeveld J, Buma AGJ (2006) Photoacclimation modulates excessive photosynthetically active and ultraviolet radiation effects in a temperate and an Antarctic marine diatom. Limnol Oceanogr 51:1239-1248

Vernet M (2000) Effects of UV radiation on the physiology and ecology of marine phytoplankton. In: de Mora S, Demers S, Vernet $M$ (eds) The effects of UV radiation in the marine environment. Cambridge Environmental Chemistry series, 1st edn. Cambridge University Press, Cambridge, pp 237-278

Vincent WF, Neale PJ (2000) Mechanisms of UV damage to aquatic organisms. In: de Mora S, Demers S, Vernet M (eds) The effects of UV radiation in the marine environment. Cambridge Environmental Chemistry Series. Cambridge University Press, Cambridge, pp 149-176

von Quillfeldt C, Hegseth EN, Johnsen G, Sakshaug E, Syvertsen EE (2009) Ice algae. In: Sakshaug E, Johnsen G, Kovacs K (eds) Ecosystem Barents Sea. Tapir Academic Press, Trondheim, pp 295-314

Wiencke C, Roleda MY, Gruber A, Clayton MN, Bischof K (2006) Susceptibility of zoospores to UV radiation determines upper depth distribution limit of Arctic kelps: evidence through field experiments. J Ecol 94:455-463

Wright S, Jeffrey S (1997) High-resolution HPLC system for chlorophylls and carotenoids of marine phytoplankton. In: Jeffrey S, Mantoura R, Wright S (eds) Phytoplankton pigments in oceanography. UNESCO, Paris

Wulff A, Roleda MY, Zacher K, Wiencke C (2008) UV radiation effects on pigments, photosynthetic efficiency and DNA of an Antarctic marine benthic diatom community. Aquat Biol 3:167-177. doi:10.3354/ab00076

Zacher K, Wulff A, Molis M, Hanelt D, Wiencke C (2007) Ultraviolet radiation and consumer effects on a field-grown intertidal macroalgal assemblage in Antarctica. Glob Change Biol 13:1201-1215 